\title{
Correction to: A comparative study of dementia knowledge, attitudes and care approach among Chinese nursing and medical students
}

\author{
Yao Wang ${ }^{1 *}$, Lily Dongxia Xiao ${ }^{1,2^{*}}$ and Rong Huang ${ }^{1}$
}

\section{Correction to: BMC Med Educ 20, 436 (2020) \\ https://doi.org/10.1186/s12909-020-02365-1}

Following publication of the original article [1], we have been informed that the author Rong Huang was incorrectly affiliated to "College of Nursing and Health Sciences, Flinders University, Adelaide, South Australia, Australia"

The correct affiliation is:

Xiangya School of Nursing, Central South University, Changsha, Hunan Province, China

The original article has been corrected.

\section{Author details}

'Xiangya School of Nursing, Central South University, Changsha, Hunan

Province, China. ${ }^{2}$ College of Nursing and Health Sciences, Flinders University, Adelaide, South Australia, Australia.

Published online: 26 November 2020

\section{Reference}

1. Wang Y, et al. A comparative study of dementia knowledge, attitudes and care approach among Chinese nursing and medical students. BMC Med Educ. 2020;20:436. https://doi.org/10.1186/s12909-020-02365-1.

The original article can be found online at https://doi.org/10.1186/s12909020-02365-1.

*Correspondence: sweet0131@163.com; lily.xiao@flinders.edu.au

'Xiangya School of Nursing, Central South University, Changsha, Hunan Province, China

Full list of author information is available at the end of the article

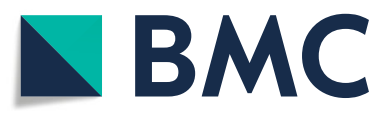

( The Author(s). 2020 Open Access This article is licensed under a Creative Commons Attribution 4.0 International License, which permits use, sharing, adaptation, distribution and reproduction in any medium or format, as long as you give appropriate credit to the original author(s) and the source, provide a link to the Creative Commons licence, and indicate if changes were made. The images or other third party material in this article are included in the article's Creative Commons licence, unless indicated otherwise in a credit line to the material. If material is not included in the article's Creative Commons licence and your intended use is not permitted by statutory regulation or exceeds the permitted use, you will need to obtain permission directly from the copyright holder. To view a copy of this licence, visit http://creativecommons.org/licenses/by/4.0/. The Creative Commons Public Domain Dedication waiver (http://creativecommons.org/publicdomain/zero/1.0/) applies to the data made available in this article, unless otherwise stated in a credit line to the data. 